\title{
Professional and Career Development of Vocational Subject Teachers as a Trend in the Lifelong Learning of Teachers
}

\author{
Viola Tamášová*
}

\begin{abstract}
This research study concerns the trends in the lifelong learning of teachers including self-education as a form of teacher personal development. It explores the importance, role and objectives of lifelong learning, andragogic pedeutology, as well as the trends and further education of possibilities of teachers in Slovakia with regards to the forms of learning, qualification education and continuing education. We present the findings of a research survey on the educational needs of secondary vocational school (SVS) teachers as one of the results of the KEGA 005 DTI-4/2013 project in the study. We also present the research objectives, research questions, research sample of SVS teachers, research methods and instruments. In addition to presenting the findings of the current and updated education needs of SVS teachers in the sample and their interpretation, we formulate the research conclusions on the educational needs of SVS teachers as one of the results of the KEGA 005 DTI-4/2013 project.
\end{abstract}

Key words: lifelong learning of teachers, self-education, andragogic pedeutology, qualification and continuing education.

\section{Introduction}

The quality of teaching depends to a great extent on the quality of the concept of lifelong professional development, the definition of its functions, goals, content, types, forms and methods as well as its organization and the interrelation between this concept and continuing education and self-education which have already become a part of lifelong learning as an EU-wide tendency. Lifelong learning of teachers is performed on a voluntary basis, based on their own need to expand their professional development and to meet social requirements

\footnotetext{
* Viola Tamášová, Dubnica Institute of Technology in Dubnica nad Váhom, Dubnica nad Váhom, Slovakia; tamasova@dti.sk
} 
resulting from economic, cultural, historical and social changes (see, e.g. Zelina, 2014).

\section{Professional Development of Teachers}

There are varying opinions on the nature and content of the frequently-used term professional development of teachers in many literary sources. Its legal basis is outlined in the Ministry of Education of the Slovak Republic Regulation 42/1996 Coll. This legislation, governing the organization, content, scope and modalities of the further training of educators, defines the purpose of professional personal development of teachers as a "Continual deepening, improving and expanding of the professional and educational competence of teachers, in accordance with the latest progressive scientific knowledge, social needs and requirements of educational and professional practice." The Act of the National Council of the Slovak Republic (NR SR) 386/1997 Coll. on further education, as amended, defines further education as "A part of lifelong learning which is, along with compulsory, secondary and higher education, the fourth pillar of lifelong learning. It is the education that allows everyone to complete, broaden and deepen acquired knowledge, to be retrained, to satisfy their interests or to prepare for the completion of a particular level of education."

Types of this education are:

- education focused on achieving a certain level of education;

- professional education and training to broaden and deepen knowledge and skills;

- hobby education and civic education.

The Act of the National Council of the Slovak Republic 568/2009 Coll. on lifelong learning and on amendments to certain Acts specifies further education as "education in educational institutions of further education which follows school education and provides an opportunity to obtain partial or full qualification or to supplement, renew, extend or deepen qualifications acquired in school education or to satisfy interests and gain better competence in civil society participation."

The term continuing professional education is more concise and therefore also more frequently used. According to Š. Švec (2002), this term is considered characteristic and adequate for the current theory and practice of the permanent professional development of teachers. Its content captures the reality of the professional development of teachers more than the previously used ambiguous term further education, which is mainly used when referring to vocational training after leaving secondary school.

\subsection{Continuing teacher education}

The term continuing teacher education is mentioned and understood as continuing education which, according to Pavlov, follows previous education 


\section{Acta Technologica Dubnicae \\ volume 5, 2015, issue 1}

obtained in the formal education process and includes further career development and self-education as one of its forms (Pavlov, 2002). Gavora and Mareš in English-Slovak pedagogic dictionary (1998) define the professional growth of teachers on the basis of competence-building with the term professional development of teachers.

According to some experts, when dealing with the issue of continuing education in Slovakia (e.g. Kosová, 2001; Kasáčová, 2002), it is important to emphasize the need of continuous lifelong learning and to establish the objective of ensuring continuing professional development of teachers as individuals and, at the same time, development of the profession in general. The concept of professional development of teachers in the career system is inevitably linked to education as a prerequisite for professional growth. The professional development of teachers is characterized by certain particularities (e.g. quality of performance, level of self-identification with the profession, requirements imposed on teachers) which represent specific stages - phases of the career path (Průcha, 1997, cited in Kasáčová, 2006, p. 27).

Table 1 Teacher career path phases

\begin{tabular}{|l|l|l|}
\hline Career path phase & $\begin{array}{l}\text { Steps and stages in life, } \\
\text { characteristics }\end{array}$ & Age period \\
\hline $\begin{array}{l}\text { 1. Choice of the teaching } \\
\text { profession }\end{array}$ & $\begin{array}{l}\text { Motivation to study } \\
\text { teaching }\end{array}$ & $\begin{array}{l}\text { up to 18-19 years of } \\
\text { age }\end{array}$ \\
\hline 2.Preparation phase & Pre-graduate training & up to 24 years of age \\
\hline 3. Career start & Start in the profession & $\begin{array}{l}\text { at about 24 years of } \\
\text { age }\end{array}$ \\
\hline 4.Career adaptation & $\begin{array}{l}\text { Experience of the first } \\
\text { years of practice }\end{array}$ & $\begin{array}{l}\text { 24 to about 30 years of } \\
\text { age }\end{array}$ \\
\hline 5. Career advancement & $\begin{array}{l}\text { Career development of } \\
\text { the teacher }\end{array}$ & about 30 - individual \\
\hline $\begin{array}{l}\text { 6.Career stabilization or } \\
\text { migration }\end{array}$ & $\begin{array}{l}\text { Remaining in the } \\
\text { profession, career } \\
\text { advancement - } \\
\text { continuing education, } \\
\text { change of the teaching } \\
\text { profession }\end{array}$ & from 35 years of age \\
\hline 7. Career extinction & $\begin{array}{l}\text { Tedious routine - } \\
\text { pedagogical } \\
\text { conservatism, leaving the } \\
\text { profession }\end{array}$ & individually \\
\hline
\end{tabular}

Source: Kasáčová (2006, p. 27) 


\section{Acta Technologica Dubnicae \\ volume 5, 2015, issue 1}

We will proceed from this source when analysing individual phases. The phase Choice of the teaching profession and the Preparation phase are not typical periods for consideration of the professional development of teachers. The first phase is characterized by contemplations on the future (career choice during secondary school studies, information on teaching perspectives, advantages and disadvantages of the teaching profession and so on). The second phase is Preparation (pre-graduate) stage which is also characterized by collecting information about the profession, but already at the level of active study of pedagogy, didactics etc., or specialization (vocational subjects). Motivation is the basis of both phases.

Career start phase - entry into the profession - is the first stage which, according to Kasáčová (2006, p. 28), defines the position of novice teachers as an important step in their career paths. The role of a student changes into that of a teacher who assumes the responsibilities previously held by someone else and takes over responsibility for their own lives. The following phases, Professional adaptation and Career advancement, are the periods when teachers gain their own first experience and develop as professionals and as people. The actual development of teachers proceeds to the stage of experienced teacher - practicing professionals in their field who establish working habits, handle work-related stress, are able to deal with challenging situations based on their own experience, attitude and working habits have the nature of positive routines and he are well-informed and knowledgeable in their fields. The Professional stabilization phase is the period of consolidation of teacher professional skills and their status in the community of educators or a shift from teaching practice to management positions in the educational system. The above phase cannot be clearly defined in time or delimited. The last phase - Professional extinction phase - is regarded as a "preretirement" period; however, this cannot be generalized. Not all teachers experience burnout in this period. In the present time, the onset of this phase can be accelerated by social and economic factors (loss of motivation, stagnation, burnout syndrome, low work appreciation, need to change the work environment, emotional burnout, etc.) which occur more (and more) frequently in the younger generation of teachers (Kasáčová, 2006). Pre-graduate training represents the initial stage, and an integral part, of the teacher education process, following one of the fundamental principles in education: teachers are not fully prepared for their profession only by completing their studies. As Kasáčová emphasizes, this principle, when observed, would ensure meeting the conditions and requirements for a solid career start and providing a wide scope of professional knowledge and skills. Self-education is regarded as an integral part of the career path of teachers and it is an important factor in improving the quality of teaching, maintaining and continuously improving the social status of the teaching profession, an integration of new knowledge into current practice. The escalation, expansion, renewal and specialization of professional competence is ensured by the system of continuing education characterized by the properties of continuity and lifelong learning. The 
goals of the education system are to develop and strengthen the professional attitudes that lead to the stabilization of the teaching profession and promote the career growth (Kasáčová, 2002).

\section{The importance, functions and objectives of lifelong learning}

The fourth pillar of lifelong education allows teachers to prepare for a higher level of education, to complete, extend or deepen already acquired education or to change qualifications, as well as satisfy the teachers' interests and needs, states Porubská (2005). If an adult wants to maintain a certain standard of living and certain level of cognitive and non-cognitive skills, active lifelong self-education is necessary. This principle is considered vital in the teaching profession, because teachers must constantly reflect on the changes in science, technology, art, economy, as well as on the cultural, historical and social changes. Only then, are the teachers able to constantly convey new information to students and give them the concept of objective reality, reflecting reality and the virtual world (Tamášová and Sári et al., 2012).

Currently, considerable attention needs to be given to the constantly growing tendency of various social and educational problems of students in the family or at school. These compel teachers to gather information, find specialized literature or attend seminars (outside their teaching competence or studied specialization which is their main area of expertise) in psychology and new teaching approaches to get guidance and find alternative solutions to fundamental problems in social and interpersonal relations at school (see, e.g. Zelina, 2014; Bajtoš, 2013).

On the basis of the foregoing, and in accordance with Porubská (2005), it can be stated that the continuing education of teachers affects two basic areas:

- Private - teachers educates themselves to satisfy their own (selfeducational) needs and interests, that is, they pursue their individual life interests and needs (e.g. family life, stress resistance, etc.) by selfeducation.

- Public - teachers educate themselves to pursue professional and social interests (e.g. easier and more available ways of problem-solving in the school environment).

\subsection{Andragogic Pedeutology}

Andragogic Pedeutology is a relatively new discipline of the andragogical field which focuses on the professional competence improvement and hobby education of teachers. It is an applied discipline of andragogy which, from the methodological point of view, belongs to a major science branch of educational science, along with pedagogy. According to Porubská and Határ (2009), andragogic pedeutology puts significant emphasis mainly on: self-improvement, 


\section{Acta Technologica Dubnicae \\ volume 5, 2015, issue 1}

self-education of educators, the role of the education of teachers, goals, methods, forms, means of education and training of teachers, lecturers, tutors, teachers of vocational training, educational advisors, etc. It approaches these issues in an interdisciplinary and trans-disciplinary way, thus contributing to the improvement of the reputation of teaching as a profession and its prestige in contemporary society.

Porubská (2005), in her work pays attention to continuing teacher education as the education of adults and examines the purpose, functions and objectives of education with their individual, community and social impact from the pedagogical point of view. Education and training pursue two types of objectives: autonomous and heterogeneous. Based on the above facts she states that the continuing education of adults - teachers contributes to: 1. the personality development of an adult (individual-personal aspect), 2. human resources development (socio-professional aspect). According to Porubská (2005, p. 100): "It is not right if the interests of society are strictly preferred to the interests of the individual... Therefore, it is necessary to consider individual needs, as well as the needs of all of society and thus aim towards a certain social consensus."

Pavlov (2002) examines the issues of continuing education in a similar way to Porubská (2005); however, his definitions of the purpose, objectives and functions differ in the matter of the whole system of continuing education. The main requirement for the effective use of teachers' potential in the educational sector is to ensure that teachers understand the overall situation in cases where:

- performance requirements imposed by the education system change constantly;

- there are changes of an economic, political, social, historical and demographic nature;

- teachers are overwhelmed with new requirements of educational sciences imposed on the teaching profession.

He divided the functions of education into: primary functions, including:

- Compensation - this means maintaining adequate level of professional competence throughout career path and compensating for the usual routine and outdating (not in terms of correcting and sorting out the omissions from the pre-gradual training).

- Expansion - represents the need to proceed towards better professional and pedagogic competence (e.g. qualification subjects) or towards obtaining a specialization in selected school positions and responsibilities (the term retraining is not considered adequate in this context).

- Adaptation (introduction) - adaptation to the needs and conditions of the school and teaching in the early years of teaching practice.

- Innovation - as a condition of continual development and improvement of the professional quality of teachers and education as a system. The 


\section{Acta Technologica Dubnicae \\ volume 5, 2015, issue 1}

Department of Education can influence the focus of teachers and their capability of taking action (for example in realizing planned changes) in a relatively short timeframe through the development of new professional competences. This represents the necessary link between the pedagogic theory and practice, between the proposed reforms and their application in school practice.

- Motivation (for self-improvement) - its aim is to deepen and reinforce selfeducational habits and skills as well as motivation for professional and personal development in the spirit of the principle: appropriately organized and meaningful continuing education as an incentive for lifelong learning.

The secondary functions are described as follows:

- deeper insight into the problems of educational practice and everyday civil life

- better mutual relationships of teachers

- exchange of experience

- opportunities to visit other places, schools, which brings about:

- the possibility of benefitting from increased susceptibility to the situation;

- the possibility of different perspectives from which to see the problems of students or colleagues;

- the early detection of the onset of work stereotypes, dogmatism, burnout syndrome.

The continuing education objectives, usually expressed in many reform proposals, are often mistaken for institutional objectives or for the content thereof, or are difficult to reconcile with other elements of the teachers' education system as a whole (Jankovičová, 2014). The final aim of continuing education, according to Zelina, is to improve the education of adults and its practical target is to improve the work of teachers at all levels of schools and educational institutions, in all organizational and professional areas (Zelina, 1996, cited in Pavlov, 2002). However, the intrinsic motivation of teachers is the incentive for the continuing education of teachers. Educational and incentive systems for continuous professional development constitute the basis for the concept of continuing education. This premise also suggests a new methodology and organization for the whole system of education. The Slovak Republic, as a member state of the European Union, has sufficient support for the improvement of the quality of education and for innovation in education programs.

Every educated teacher or professional educator is aware that the competences, knowledge, skills and habits acquired during school time are no longer enough. Further training is a necessity, either within the school system, after-school or informal education, education of adults (depending on the possibilities of the organization, facility, institution) or through their own efforts, teachers need to enhance their knowledge, awareness in their fields and personal competences. 


\section{Continuing education of teachers}

There are several categories in the system of continuing education:

* Organized continuing education of teachers, which includes:

1. Qualification education,

2. Continuous education

\section{** Self-education of teachers}

Each of these types of continuing education should be seen as a branch of education comprising other related forms. The National Education Program focuses mainly on the creation of favourable conditions that can help promote self-education, which is considered the most effective way of learning (Turek, 2009).

In this context it is necessary to pay attention to the issue of the relation between formal, non-formal and informal (non-institutional) education of teachers, based on the characteristics of lifelong learning, which includes:

- Formal learning - refers to the institutions designated for education and training which ends with official certification and qualification;

- Non-formal learning - is parallel to the main education (outside school) and is not completed by an official certificate (e.g. civic associations, hobby centres, etc.);

- Informal learning (non-institutional) - is a natural part of everyday life, it may not be intentional and conscious; the "learner" may not even be aware of how it contributes to the enhancement of his knowledge and skills (Švec, 2005).

Statistics show that the population of teachers across Europe is slowly aging and the demographic situation in most countries is causing postponed retirement. As a result of this factor, the importance of pre-gradual training as a formal means of education and as a facilitating factor for progressive change and innovation in education is reduced and often overlooked. The educational policy of the EU countries focuses on lifelong learning (EU Memorandum On Lifelong Learning) which assumes greater responsibility and a support role in promoting the necessary reforms and qualitative changes (Memorandum on Lifelong Learning, 2001).

The question that needs to be answered - in what areas should teachers be educated, what should continuing education involve - has a simple solution: education in all current issues for which the young people, as the potential new generation of teachers and educators, need to be prepared: this is the European trend, according to Tamášová (2005). It is necessary to emphasize the condition that nothing can be excluded from the content of continuing education of teachers, thus the extent of the question becomes exceptionally wide. According to Kasáčová (2006), the teacher education programs can be categorized by objective and content as follows: 
1. Adaptation - Suitable for graduates of pedagogical colleges and novice teachers;

2. Specialization - Designed to prepare for specialized tasks in school;

3. Functional - The training of teaching staff supervisors;

4. Innovation - Suitable for teachers who adopt innovative strategies and alternative teaching methods;

5. Updating - Suitable training for teachers to maintain teaching competences for the profession;

6. Specialized innovation (implemented innovation) - Designed for teachers and teaching staff supervisors to restore (reaffirm) their professional competences;

7. Qualification - Provides an extension of previous professional and educational qualifications with new certified courses (Kasáčová, 2006).

\section{Survey on the educational needs of SVS teachers as one of the results fo the KEGA project}

The objective of this research study, which was established as a part of the KEGA 005DTI-4/2013 research project "Socio-educational training as an innovative form of lifelong education teachers of secondary vocational schools" (project presented in detail in Hlásna, 2013 a, b), was to describe the fundamental components of the lifelong learning of teachers, the position of creative drama as one of the forms of experiential and lifelong teacher education in socio-educational training (SET). One of the outcomes produced in the project's implementation was also research carried out on a specific sample of teachers at secondary vocational schools focusing on two areas. The research is described in detail in the following chapter.

\subsection{Research objectives and research questions}

The research hasfocused on two main objectives:

Objective 1 - To develop qualitative-qualitative content analysis of the text of the self-reflection of teachers of secondary vocational schools based on the completion of educational activities - socio-educational training as part of KEGA 005DTI-4/2013, whose theoretical basis has been described in the publication Socio-educational training as an innovative form of lifelong learning of secondary vocational school teachers I.,

Objective 2 - To conduct a survey on the further educational needs of our target group, namely secondary vocational school teachers. We have set these two main objectives: 


\section{Acta Technologica Dubnicae \\ volume 5, 2015, issue 1}

1. Objectives concerning the socio-educational training ${ }^{1}$;

2. Objectives related to the analysis of the educational needs of these specific target groups and to the identification of the further education needs of the target groups.

\section{Research questions}

Research questions were set also for the Objectives group $1^{2}$.

The research questions for Objectives 2:

- What are the current educational needs of this specific target group of SVS teachers?

\subsection{Research sample of SVS teachers}

Socio-educational training was prepared by a team of project researchers in terms of objectives, content, selection of activities and their implementation, especially with regards to previous positive experience in teaching. Participants in this free socio-educational training were recruited by means of personal contact and through the promotion of socio-educational training on the DTI website and Regional Boards of Education. The advantage for teachers was the possibility to undergo SET (mostly) at their home school.

The research sample selection was not strictly random; it was contingent on the willingness of directors and teachers to implement the socio-educational training for school teachers. One of its outcomes was teachers' self-reflection and a questionnaire focusing on the further educational needs of this target group. Socio-educational training in 2013 and 2014 under the KEGA project involved altogether 121 secondary vocational school teachers (100 women and 21 men). We had to eliminate a group of 20 teachers from the Bratislava region, since this group did not meet the specified requirements for research. Overall, we were able to include 101 teachers ( 87 women and 14 men) in the survey.

Writing a (self-)reflection and filling in the questionnaire after completion of the educational activities was voluntary. The whole sample of people involved in the research can be characterized in terms of objectives 1 and 2 .

In terms of research objective $1^{3}$

In terms of research objective 2:

1. Gender of the respondents - questionnaires were completed by 87 teachers 76 women, accounting for $87.4 \%$ of the sample and 11 men, accounting for $12.6 \%$ of the sample;

2. Location of school - questionnaires were filled out by teachers of secondary vocational schools in three self-governing regions of the Slovak Republic (Bratislava, Trnava, Trenčín), teachers of one school in Bratislava (Bratislava region), teachers of three secondary schools in Trnava (Trnava

\footnotetext{
${ }^{1}$ This part of the research was described in Čepelová and Krásna (2014)

${ }^{2}$ This part of the research was described in Čepelová and Krásna (2014)

${ }^{3}$ This part of the research was described in Čepelová and Krásna (2014)
} 


\section{Acta Technologica Dubnicae \\ volume 5, 2015, issue 1}

region), teachers of one secondary vocational school in Senica (Trnava region), teachers of one high school in Sered' (Trnava region), teachers of two secondary schools in Trenčín (Trenčín region), teachers of one secondary vocational school in Považská Bystrica (Trenčín region);

3. Type of school (the teachers' workplace) - teachers of secondary vocational schools.

\subsection{Research methods and research tools Research methods}

Empirical methods of education research facilitate the detection of specific, unique characteristics of the phenomenon examined which exists in objective reality. They are represented in the research by both quantitative and qualitative methods which allow the analysis and evaluation of so-called latent/hidden data and information. The methods listed below were applied in following way:

$>$ Descriptive method was used to cover the description of the examined topic at theoretical and empirical level;

$>$ Qualitative-quantitative content analysis of the text was used due to the wide range of possible applications in education, allowing examples to be analysed in teacher feedback etc.;

$>$ Analysis dividing the whole into parts and examining the connections among them was used as a general research method for example when analysing the educational needs of the target group;

$>$ Synthesis, which is one of the fundamental methods and thought processes and is based on linking the individual component parts to a whole, was used, for example, in the analysis of the (self-)reflections of teachers;

$>$ Analytic-synthetic methods, combining both the previously mentioned processes, were used with regards to the established research objectives and in line with the extent and proportion necessary for a successful resolution of the research task;

$>$ Induction is a fundamental cognitive process and, as a scientific method, it represents the most important form of reasoning; e.g. in the process of analysing the (self-) reflection of teachers;

$>$ Deduction was used as a way of proceeding from the general to the unique and as a tool to draw conclusions from both studies and to formulate the research statements of various degrees of generality;

$>$ Inductive-deductive method was used as a combination of the two previously listed methods in terms of both main research objectives;

$>$ Comparison was used to determine the similarities and differences between the phenomena studied in both parts of our research survey;

$>$ Classification, i.e. sorting the elements of the whole, was applied according to previously chosen classification criteria with regards to the established objective, resulting in an organized set of phenomena occurring among the elements of the emerging system in both parts of our research; 


\section{Acta Technologica Dubnicae \\ volume 5, 2015, issue 1}

$>$ Generalization was used in both parts of the research and in the research stages for transition from individual to general and from less general to more general knowledge.

It is necessary to bear in mind that the social sciences - including pedagogy - as well as other human sciences retain their empirical character necessary for scientific research and maintain the empirical character necessary in scientific research; so when dealing with existing and newly emerging specific features of pedagogy, we apply the following methods and tools.

\section{Research Tools}

The tools used for the Objective 1 were the self-reflections of the teachers, where the teachers were encouraged to honestly express their opinion, their own point of view of their socio-educational training and self-evaluation. The form and contents of the self-reflections was up to the teachers; however, some of them requested some guidance; which is described in more detail in the publication focusing on the socio-educational training as an innovative form of lifelong learning of secondary vocational school teachers ${ }^{4}$.

For Objective 2 the research method used was a questionnaire serving primarily as feedback after completing the socio-educational training which included a survey of the educational needs of the participating SVS teachers as a specific target group.

The collected responses could be classified in three significant basic categories (even though any clearly defined and unambiguous categorization is prevented by their overlapping):

1. Educational needs in relation to lesson planning and teaching;

2. Educational needs in relation to self-education;

3. Educational needs in relation to tutoring and further assistance to the students.

\section{4 Results of the survey of current and updated education needs of SVS teachers in the sample and their interpretation}

1. Educational needs in relation to lesson planning and teaching - as can be seen from Table 1, the highest number of SVS teachers in our sample expressed the need for further education in the field of (didactic) games in the teaching of vocational subjects, languages etc. at secondary vocational schools - on the basis of the analysed (self-)reflection responses from the teachers in our sample we assume that they not only want to know such games, but want to try them out and apply them directly during their work with students.

The second most frequent area of educational needs expressed by the teachers was activating methods of teaching at secondary vocational schools. This area is

\footnotetext{
${ }^{4}$ Čepelová and Krásna (2014)
} 


\section{Acta Technologica Dubnicae \\ volume 5, 2015, issue 1}

closely linked with the first one, since (according to experts in general and specialized didactics) didactic games belong to activating and, at the same time, to innovative methods of teaching various subjects (not only) at SVS. That brings us to the conclusion that teachers participating in the socio-educational training are willing to work on themselves to improve the quality of their teaching, they are willing to make an effort and learn new things which can be used in their work with students. At the same time they emphasize the necessity of using new innovative methods of teaching at secondary vocational schools.

The third most frequently mentioned area of educational needs in our sample was motivating the students during their secondary education. In this regard it is important to note that in addition to the quality of their own work, teachers care about the motivation of their students to learn and achieve better learning results. The above statement is also supported by the fact that creative teaching methods and student creativity development in secondary education were the next areas of interest of our target group. Project-based learning, student team work, experiential teaching, specific methods of creative drama and their use at secondary vocational schools, as well as problem solving tasks, can be classified among activating and innovative teaching methods at secondary vocational schools. This further supports the significance of the most frequently mentioned educational needs of the SVS teachers in our sample with regard to the teaching process.

Tab. 2 Educational needs of the SVS teachers in the sample in relation to lesson planning and teaching

\begin{tabular}{|l|c|c|}
\hline Education need & Number & \% \\
\hline $\begin{array}{l}\text { (Didactic) games in teaching vocational, language and } \\
\text { other subjects at secondary vocational schools }\end{array}$ & 32 & 36.8 \\
\hline $\begin{array}{l}\text { Activating teaching methods of students at secondary } \\
\text { vocational schools }\end{array}$ & 17 & 19.5 \\
\hline $\begin{array}{l}\text { Innovative approaches to teaching subjects at secondary } \\
\text { vocational schools }\end{array}$ & 16 & 18.3 \\
\hline Motivating students in the secondary education process & 14 & 16 \\
\hline
\end{tabular}

Source - own research

Several teachers in the sample (less than $10 \%$ of teachers who completed the questionnaires) singled out the following educational needs in relation to lesson planning and teaching:

- Creative teaching, developing students creativity at SVS - 7 teachers;

- Project teaching methods at SVS - 5 teachers;

- Teamwork in a group of students at SVS - 4 teachers;

- Experiential learning at SVS - 3 teachers;

- Creative Drama and its application at SVS - 2 teachers; 


\section{Acta Technologica Dubnicae \\ volume 5, 2015, issue 1}

- Fundamental competences of a SVS teacher - 2 teachers;

- New forms of testing SVS students - 1 teacher;

- New forms of SVS student assessment - 1 teacher;

- Problem-solving activities in the classroom at SVS - 1 teacher.

It was the area of continuing education mentioned only by one teacher, specifically the new forms of testing, verification of knowledge and assessment of students that caught our attention. We believe that this kind of well-arranged teaching activity might be interesting and beneficial for the SVS teachers in terms of fundamental student skills and competences and also with regard to new types of course-books, teaching materials or new forms of student assessment.

2. Educational needs in relation to teacher self-education - as can be seen from Table 2, most of the SVS teachers in our sample expressed the need for further education in the field of self-knowledge. The analysed self-reflection of the teachers in our sample also suggests that there is some uncertainty and doubt in this area. The teachers in our sample seem to assume that a lot of difficulties in the teaching process might be caused by their weaknesses and that further education would help them recognize and work with these weak spots, which could, as we believe, have a positive effect on the everyday teaching activities of teachers and their work with the students.

The second most frequently mentioned area of further education needs expressed by teachers was self-education. It would be interesting to find out what methods and procedures of self-education the teachers have been using so far, how effective the methods have been and what the teacher motivation was. Based on the teachers' reflections we assume that a series of socio-educational training would be an appropriate option and an acceptable form of personal development. The third most frequently mentioned area of additional education needs reported in our sample were communication skills. We assume that teachers do not feel the lack of communication skills during the lessons and presentation of taught material but that this area is linked to the fourth most frequently stated area of further education needs of SVS teachers in our questionnaires, which is stressresistance, handling stress, handling mental strain and difficult situations and teachers' mental health.

All of the above areas may play a vital role in self-assessment, in various ways of dealing with everyday challenges in direct educational activities and working with students, in communicating and handling difficult situations in relation to students, colleagues, parents, superiors etc. The fact, that the fifth most frequently mentioned area of educational needs of our target group was personal growth. Personal development of SVS teachers further supports our findings, as the two areas mentioned above might form a significant part of teachers' personal development. 
Tab. 3 Educational needs of SVS teachers in our sample in relation to selfeducation

\begin{tabular}{|l|c|c|}
\hline Education need & Number & $\mathbf{\%}$ \\
\hline Self-knowledge & 20 & 22.9 \\
\hline Self-education & 16 & 18.4 \\
\hline Communication skills & 15 & 17.2 \\
\hline $\begin{array}{l}\text { Resistance to stress, stress management, dealing with } \\
\text { mental strain, handling difficult situations }\end{array}$ & 12 & 13.8 \\
\hline Mental health & 12 & 13.8 \\
\hline Personal growth, personal development & 11 & 12.6 \\
\hline
\end{tabular}

Source - own research

Some SVS teachers (less than $10 \%$ of teachers who filled out the questionnaires) identified the following educational needs in relation to lesson planning and teaching:

- Educational and psychological training for SVS teachers - 5 teachers;

- Foreign language (English) - 3 teachers;

- Addressing conflict situations with colleagues, school board and supervisors - 3 teachers;

- Solving problematic situations - 3 teachers;

- Psycho-social skills - 1 teacher;

- Digitization, ICT (Information and communications technology) skills - 1 teacher;

- Physical education and sport - 1 teacher.

We find it interesting that the statements in the questionnaires included neither educational needs in the area of revision, nor renewal of knowledge in their area of expertise, specialization or qualification, nor further career growth, e.g. functional training with a view to management positions. Even ICT skills and digitization as areas of continuing education appeared only once in the questionnaires. Therefore, we conclude that a lot of measures have been taken and a lot of opportunities created, which have resulted in the desired effect. At the same time, the teachers, recognizing the necessity of technology in the modern age, have done a lot of work in the area of self-education and progress to higher digital literacy.

3. Training needs in relation to guidance and educational activities for students - Table 3 shows that the highest number of SVS teachers in the sample expressed the need for further education in this field, in particular in relation to working with difficult secondary school students. On the basis of this considerably high preference (this requirement was formulated by more than $44 \%$ of participants in our study), we believe that these training activities should 


\section{Acta Technologica Dubnicae \\ volume 5, 2015, issue 1}

be offered to teachers with their active participation in creating the training programs in order to target the majority requirements.

We also assume that the above requirement is closely related to solving conflict situations with students, which ranked as second most frequent. Obviously, problematic situations in teacher-student relationships, including conflicts, pose a challenge for teachers in their daily educational practice, probably making them try various approaches (student participants of a survey performed in Slovakia reported also physical and psychological punishment by teachers). We believe an appropriate solution would be a series of meetings with experts, each meeting focusing on one of the most visible and most problematic areas, where the teachers could confront their practice in cooperation with psychologists, special pedagogues, educators, advisors, pathopsychologists, doctors, therapists, psychiatrists etc. and look for viable strategies for educational practice with this age group.

The next educational need expressed by the teachers in our sample was training in relation to form teacher responsibilities. Teachers often assume the role of a form teacher with no specific preparation during the university studies or previous teaching practice and it is obvious that self-study is not sufficient in this case.

Another area of educational requirement mentioned by our participants was working with integrated students with special educational needs or students with learning difficulties at secondary schools. Although this is not the solitary responsibility of the secondary school teacher - there needs to be cooperation on the part of students, parents, form teachers, colleagues, school boards, special pedagogues, tutors, psychologists, paediatricians, neurologists; clearly many teachers would welcome help, guidance and support in contrast to the general expectation that teachers are the ones to guide others.

Tab. 4 Educational needs in relation to tutoring and further assistance to the students (U)

\begin{tabular}{|l|c|c|}
\hline Education need & Number & \% \\
\hline Working with difficult SVS students & 39 & 44.8 \\
\hline Handling conflict situations with students & 14 & 16 \\
\hline Continuing education of form teachers & 11 & 12.6 \\
\hline $\begin{array}{l}\text { Working with integrated students, students with learning } \\
\text { difficulties }\end{array}$ & 9 & 10.3 \\
\hline
\end{tabular}

Source - own research

Some SVS teachers (less than $10 \%$ of teachers who filled out the questionnaires) identified the following educational needs in relation to teaching:

- Psychology of secondary vocational school students - 8 teachers;

- Leading a group, working with teams of students in classes - 4 teachers; 


\section{Acta Technologica Dubnicae \\ volume 5, 2015, issue 1}

- Building relationships with students, working with students - 3 teachers;

- Working with students with poor performance - 2 teachers;

- Psychological games -1 teacher;

- Why are we so overloaded with material to be covered - 1 teacher;

- Look forward to high school - one teacher;

- Identification of problems in groups of students - 1 teacher;

- Working with students from socially disadvantaged environments - 1 teacher;

- Drug prevention - 1 teacher;

- Crime prevention - 1 teacher;

- Social relationships in the classroom - 1 teacher.

\subsection{Research findings based on the survey of education needs of SVS teachers}

The above research was focused on the detection of additional educational needs of secondary vocational school teachers. We tried to identify further current educational needs of this specific target group of secondary school teachers. The main tool was the questionnaire, which primarily served as feedback immediately after completing socio-educational training and its important task was to inquire into the educational needs of the SVS teachers as a specific target group of teachers.

The collected responses were classified in three fundamental categories (even though any clearly defined and unambiguous categorization is prevented by their overlapping):

a. Educational needs in relation to lesson planning and teaching;

b. Educational needs in relation to self-education;

c. Educational needs in relation to tutoring and further assistance to the students.

The classified findings have been described in more detail in subsection 4.4. In terms of overall results, the most preferred areas of educational needs of the target group of our research have been arranged and summarized in the following chart.

Tab. 5 Most preferred educational needs of secondary vocational school teachers based on the results in the sample

\begin{tabular}{|l|c|l|}
\hline Education need & Number & $\mathbf{\%}$ \\
\hline Working with difficult SVS students & 39 & 44.8 \\
\hline $\begin{array}{l}\text { (Didactic) games in teaching vocational, language and other } \\
\text { subjects at secondary vocational schools }\end{array}$ & 32 & 36.8 \\
\hline Self-knowledge of SVS teachers & 20 & 22.9 \\
\hline $\begin{array}{l}\text { Activating teaching methods at secondary vocational } \\
\text { schools }\end{array}$ & 17 & 19.5 \\
\hline
\end{tabular}




\begin{tabular}{|l|c|c|}
\hline Self-education of SVS teachers & 16 & 18.4 \\
\hline $\begin{array}{l}\text { Innovative approaches to teaching subjects at secondary } \\
\text { vocational schools }\end{array}$ & 16 & 18.4 \\
\hline Communication skills of SVS teachers & 15 & 17.2 \\
\hline Motivating students in the secondary education process & 14 & 16 \\
\hline $\begin{array}{l}\text { Resistance to stress, stress management, dealing with mental } \\
\text { strain, handling difficult situations }\end{array}$ & 12 & 13.8 \\
\hline Mental health & 12 & 13.8 \\
\hline Continuing education of form teachers & 11 & 12.6 \\
\hline $\begin{array}{l}\text { Working with integrated students, students with learning } \\
\text { difficulties }\end{array}$ & 9 & 10.3 \\
\hline
\end{tabular}

Source - own research

The most frequently requested area of SVS teacher education was working with difficult students at secondary vocational schools (39 teachers, accounting for $44.8 \%$ of our sample), the second were (didactic) games in teaching (professional, language ...) subjects at secondary vocational schools (32 teachers, accounting for $36.8 \%$ of our sample) and the third area was self-knowledge of secondary school teachers (20 teachers, accounting for $22.9 \%$ of the sample).

We conducted a short-term applied empirical research. The research was of an interdisciplinary character and focused on partial objectives and areas. Several other interesting areas of continuing education of SVS teachers were suggested by the teachers participating in the research, however, their incidence was below $10 \%$ (mentioned under the Tables 1, 2 and 3), some of which might prove to be more preferred in a nationwide survey. All of the above areas are possible for the vital direct educative work of teachers at SVS; further training can help teachers deal with the everyday difficulties of educational work with students, as well as effectively cope with stressful situations in their relations with students, colleagues, parents of students, supervisors, etc. Our previous conclusions are supported by the fact that socio-educational training in the form the participants of the research experienced should be a series of continuous meetings, not just one single training session, which brings a new challenge for us - to formulate another project following up on this one that would, along with its continuations, form an important part of teacher personal development within lifelong learning.

\section{Conclusion}

The requirements imposed on teachers by society are not limited to the appropriate level of education, but also cover teacher competence in the professional, pedagogical and psychological, personal and didactic areas. Therefore, lifelong learning is a necessity for their personal growth. Educational outcomes, their quality, the educational process or achieved certificate of 


\section{Acta Technologica Dubnicae \\ volume 5, 2015, issue 1}

training and education are crucial elements. The fact that a teacher completes any training and gets a certificate does not ensure that the acquired knowledge will represent new added values for the employer, the school. The same certificate of completion of training does not represent the same quality of acquired knowledge in each individual participant of training. Personal qualities of individuals play a vital role in this regard. If a person wants to actively cope with rapid changes in society, increasing requirements in science, technology, economy and overall personal growth, it is necessary to continue learning throughout their whole life. Due to the research strategy chosen, the results presented cannot be generalized to the whole population of teachers of secondary vocational schools. However, they are a useful matter for discussion on the issue of the lifelong and continuing education of teachers in Slovakia and their educational needs and an important output of the KEGA 005DTI-4/2013 project "Socio-educational training as an innovative form of lifelong learning of secondary vocational school teachers."

\section{References}

BAJTOŠ, J. Didaktika vysokej školy. Bratislava: IURA EDITION, 2013. ČEPELOVÁ, S., and KRÁSNA, S. Sociálno-pedagogický výcvik ako inovativna forma celoživotného vzdelávania učitelov stredných odborných škôl I. Brno: Tribun, 2014.

GAVORA, P., and MAREŠ, J. Anglicko-slovenský pedagogický slovnik. Bratislava: IRIS, 1998.

GERŠICOVÁ, Z., and TÓTHOVÁ, R. Sociálno-pedagogický výcvik ako spôsob d’alšieho rozvoja komunikačných a prosociálnych kompetencií študentov vysokých škôl, humanitného zamerania. DOLISRA, J. (ed.). Práce pomáhajicich profesí v oblasti zdravotnictvi a sociálni péče. Praha: Evropské vzdělávací centrum, 2010. pp. 81-85.

HLÁSNA, S. Socio-Educational Training as an Innovative Form of the Lifelong Education of Teachers at Secondary Vocational Schools - Project KEGA no. 005DTI-4/2013. Acta Technilogica Dubnicae, 3, 2013a, 1, p. 94-96.

HLÁSNA, S. Sociálno-pedagogický výcvik ako inovatívna forma celoživotného vzdelávania učitel'ov stredných odborných škôl - Project KEGA n. 005DTI4/2013. Jazykovedné, literárnovedné a didaktické kolokvium XIX. Bratislava: ZF LINGUA, 2013b. pp. 160 - 161.

JANKOVIČOVÁ, M. Sebavzdelávanie ako forma profesného rozvoja učitel'a ekonomických predmetov na strednej škole. Diploma thesis. Dubnica n/Váhom: DTI, 2014.

KASÁČOVÁ, B. Profesný rozvoj učitel’a. Prešov: Rokus s.r.o., 2006.

KASÁČOVÁ, B. Učitel' - profesia a príprava. Banská Bystrica: PF UMB, 2002. 


\section{Acta Technologica Dubnicae \\ volume 5, 2015, issue 1}

Koncepcia celoživotného vzdelávania $v$ Slovenskej republike. [on-line]. Bratislava: Vláda SR, 25. 2. 2004. Available from: $<$ http://www.minedu.sk/data/ USERDATA /DalsieVzdel/VDOC/Koncepcia CZV. zip>

KOSOVÁ, B. Perspektívy učitel'ského vzdelávania - východiská, paradigmy a spoločenské výzvy. História, súčasnost’ a perspektívy učitel'ského vzdelávania. Banská Bystrica: PF UMB, 2002.

Memorandum o CŽV: konzultačný proces. Bratislava: EDIS, EK. Direktorát pre vzdelávanie a kultúru MŠ SR, 2001.

PAVLOV, I. Profesijný rozvoj pedagogického zboru školy. Prešov: MPC, 2002.

PORUBSKÁ, G. Manažment vzdelávania dospelých. Nitra: Pedagogická fakulta Univerzita Konštantína Filozofa, 2005.

PORUBSKÁ, G., and HATÁR, C. Kapitoly z andragogiky pre pomáhajúce profesie. Nitra: PF Univerzita Konštantína Filozofa, 2009.

PRŮCHA, J. Moderní pedagogika. Praha: Portál, 2002.

ŠVEC, Š. Základné pojmy v pedagogike a andragogike. Bratislava: Iris, 2005.

ŠVEC, Š. et al. Metodológia vied o výchove. Kvantitatívno - scientistické a kvalitativno - humanistické pristupy. Bratislava: IRIS, 2005.

TAMÁŠSVÁ, V. Celoživotné vzdelávanie pedagógov-európsky trend. Aktuálne otázky pedagogickej vedy v kontexte európskej dimenzie vzdelávania. Bratislava: Retaas, 2005. pp. 57-64.

TAMÁŠOVÁ, V., and SÁRI, M., (eds.) Quality Management System of Universities and the Quality of Education. Baja: EJ College Baja, 2012.

TUREK, I. Kvalita vzdelávania. Bratislava: IURA Edition spol. s. r.o., 2009.

Vyhláška MŠ SR 42/1996 o d'alšom vzdelávani pedagogických pracovníkov.

Zákon č. 386/1997 Z. z. zo 4. decembra 1997 o d’alšom vzdelávani a o zmene zákona Národnej rady Slovenskej republiky č. 387/1996 Z. z. o zamestnanosti v znení zákona č. 70/1997 Z. z.

Zákon NR SR 568/2009 Z. z. o celoživotnom vzdelávaní a o zmene a doplnení niektorých zákonov v znení zákona 315/2012 Z. z.

ZELINA, M. Celoživotné vzdelávanie učitel'ov a rozvoj osobnosti učitel'ov. In SVETLÍKOVÁ, J. et al. Edukačné hry v celoživotnom vzdelávani učitelov stredných odborných škôl. Brno: Tribun, 2014. 